\title{
Isolation of antagonistic fungi from rhizospheres and its biocontrol activity against different isolates of soil borne fungal pathogens infected legumes
}

\author{
ERIYANTO YUSNAWAN", ALFI INAYATI, YULIANTORO BALIADI \\ Indonesian Legumes and Tuber Crops Research Institute, Indonesian Agency for Agricultural Research and Development. Jl. Raya Kendalpayak Km 8, \\ Po Box 66, Malang 65101, East Java, Indonesia. Tel.: +62-341-801468, Fax.: +62-341-801496, `email: eyusnawan@ @itbang.pertanian.go.id.
}

Manuscript received: 3 May 2019. Revision accepted: 29 June 2019.

\begin{abstract}
Yusnawan E, Inayati A, Baliadi Y. 2019. Isolation of antagonistic fungi from rhizospheres and its biocontrol activity against different isolates of soil borne fungal pathogens infected legumes. Biodiversitas 20: 2048-2054. Soilborne diseases caused by Rhizoctonia solani and Fusarium sp. are biotic limits for legume production. Biological controls offer environmental friendly control for these pathogens. This study aimed to isolate and screen Trichoderma from different rhizospheres and to obtain effective Trichoderma isolates to suppress in vitro growth of the soil borne pathogens. The antagonistic inhibitory activity was performed by dual culture method. Seven out of forty indigenous Trichoderma isolates collected from East Java, Indonesia effectively suppressed the growth of different fungal isolates, namely Rhizoctonia solani (R.s1), R. solani (R.s2) as well as Fusarium sp. which infected soybean and mung bean. In vitro study showed different suppression of the pathogens on dual culture tests. The seven isolates inhibited the growth of $R$. solani (R.s1), R.solani (R.s2) and Fusarium sp. ranging from 90.0 to $99.6 \%, 72.8$ to $82.4 \%$, and 67.9 to $90.8 \%$, respectively. Isolate origin and genetic variability of Trichoderma played an important role in the antagonistic activity. The fast-growing of selected Trichoderma showed their abilities for space occupation and nutrition competition, which involved in the antagonistic activity. The mycelial growth of Trichoderma over pathogens showed hyperparasitism mechanism. In addition, coiling of Trichoderma over hyphal pathogens was observed during microscopic observation. The seven Trichoderma isolates, therefore, are promising as biological control agents against the soil borne fungi infected legumes.
\end{abstract}

Keywords: Antagonistic activity, dual culture, inhibition, isolation, soilborne fungi

\section{INTRODUCTION}

Wilt diseases caused by soil borne fungi are biotic obstacles to maintain yield production of legume crops. Soil borne pathogens infect many crops from seedling to generative stage. Aggressive growth of $R$. solani, for example, was able to devastate soybeans in tidal swamp area in Barito Kuala, Kalimantan Indonesia with disease severity of 50-75\% (Rahayu 2014). Another isolate of $R$. solani in combination with Fusarium sp. infected around $25 \%$ of the population of mung bean germplasm collections in Indonesia. An in-vitro study showed that $R$. solani infection in mung bean caused the reduction of survival seedling growth and wilting. Fusarium sp. acted as secondary pathogens following infection by primary pathogens, $R$. solani. High severity of wilt disease occurred in all susceptible mung bean genotypes. Wilt disease appeared from one week after planting (Setyorini and Yusnawan 2014), so precautions to control these pathogens can be carried out earlier before the emerging plant.

Management of these fungal soilborne pathogens is challenging since the fungal propagules exist in the soil, causing difficulties in controlling them. Synthetic fungicide applications such as triazole, carbendazim, carboxin, and thiram have been used to suppress the growth of $R$. solani (Akhter et al. 2015; Datta et al. 2016). However, continuous application of fungicides, particularly in an endemic area is considered unfriendly environmental control, that may affect other living organisms such as beneficial soil microbes, and also leading to strain resistance to certain active compounds of the fungicides (Sundaramoorthy and Balabaskar 2013). The use of biocontrol agents for controlling soilborne pathogens either fungi or bacteria such as Trichoderma, Streptomyces, Bacillus, and Pseudomonas as an alternative to chemical fungicides is rapidly demanding to minimize such negative effects (Woo et al. 2014).

Trichoderma spp. are well known as biocontrol agents in agriculture against a wide range of fungal pathogens such as Botrytis cinerea, Fusarium oxysporum, Sclerotium rolfsii, and Rhizoctonia solani (Mayo et al. 2015; John et al. 2015; You et al. 2016; Mahmoud and Abdalla 2018). Trichoderma is soil inhabitant fungi, which have several modes of action to inhibit fungal pathogens, such as mycoparasitism, enzyme secretion particularly chitinase and glucanase for degrading cell wall of pathogenic fungi (Küçük and Kývanç 2008). Trichoderma also produces volatile and non-volatile organic compounds which act as antibiotics (Dubey et al. 2007; Ajith and Lakshmidevi 2010).

Most studies focus on the antifungal activity of Trichoderma spp. against specific plant pathogens, such as an application of Trichoderma to control Rigidoporus microporus (Setyawan et al. 2014), the use of $T$. 
asperellum against $F$. oxysporum f. sp. cucumerinum (Saravanakumar et al. 2016), and T. asperellum to manage vascular streak dieback disease of cocoa in Indonesia (Rosmana et al. 2015). Research on antifungal properties of Trichoderma to control several pathogens either from different species or isolates or strains of the same species has not been yet extensively explored, particularly in legumes. Suppression of $F$. oxysporum and Alternaria alternate, two fungal pathogenic species causing vascular wilt and blight diseases, was achieved through systemic resistance induction by $T$. viridae on leguminous crops of Cajanus cajan, Vigna radiata, and Vigna mungo (Rao et al. 2015). Agamani et al. (2017) reported that Trichoderma spp. were effective for suppressing Rhizoctonia baticola, $F$. oxysporum f.sp.ciceri, and $S$. rolfsii on infected chickpea.

There is a need to explore indigenous potential antagonistic fungi of Trichoderma isolated from different rhizospheres to suppress the incidence of soilborne diseases, particularly infected soybean and mung bean in Indonesia. Hence, this study aimed to isolate and screen Trichoderma from different rhizospheres as well as to obtain effective strains of Trichoderma in suppressing in vitro growth of soilborne pathogens of soybean and mung bean.

\section{MATERIALS AND METHODS}

\section{Root and soil collection and isolation media}

Twenty six samples of soil and roots from different crops were collected from around East Java, Indonesia, during the cultivation seasons of 2015 and 2016. The samples were packed into separate plastic bags and transferred to Mycology Laboratory of Indonesian Legumes and Tuber Crops Research Institute (ILETRI), Malang, East Java. Potato dextrose agar (PDA) supplemented with chloramphenicol was used to isolate antagonistic fungi (Abo-Elyousr et al. 2014).

\section{Antagonistic fungal isolation}

Roots were washed and disinfected with $0.5 \% \mathrm{NaOCl}$ by dipping for 2-3 minutes, followed by washing in sterile water then air dried on sterile filter paper inside laminar air flow. The roots were placed inside a Petri dish containing PDA enriched with chloramphenicol (Abo-Elyousr et al. 2014). Soil samples collected around root crops (10 g) were diluted in $100 \mathrm{~mL}$ of sterile water to obtain $10^{-1}$ dilution, and the soil suspension was spread on PDA containing chloramphenicol.

Further dilutions of soil suspension $\left(10^{-2}\right.$ and $\left.10^{-3}\right)$ were carried out to isolate soil fungi. After three to five days of incubation, Trichoderma grown on the PDA were recultured on the PDA slant. The same procedure to identify and characterize the fungi was conducted as above.

\section{Morphological identification of antagonistic fungi}

Fungi grown and identified as Trichoderma were recultured on PDA slant. Morphological identification was carried out according to Gams and Bissett (1998). The individual fungus was cultured on PDA. Radial growth, time, and the abundance of sporulation were recorded for five days.

\section{Pathogen isolation and identification}

Soil borne pathogens were obtained from the fungal culture collection of the Mycology Laboratory, ILETRI. The soil borne pathogens were isolated from soybean infected by Rhizoctonia solani [denoted as R. solani (R.s1)] (Rahayu 2014) as well as mung bean infected by Rhizoctonia solani [denoted as R. solani (R.s2)] and Fusarium sp. (Setyorini and Yusnawan 2014). Brief general procedure for fungal isolation as follows: infected tissues were surface sterilized with $0.5 \% \mathrm{NaOCl}$, followed by rinsing with sterile water. After air dried in the laminar air flow, the infected tissue was placed inside Petri dish containing PDA amended with chloramphenicol. After five to seven days of incubation, fungi grown on the PDA was transferred to the PDA slant. The pure cultures were identified as described by Rahayu (2014), Setyorini and Yusnawan (2014).

\section{Biocontrol in-vitro test}

Dual culture in-vitro test of Trichoderma against soil borne fungi was performed according to John et al. (2010) with minor modification. Five-day old of Trichoderma and 7-day old of soil borne fungi were cut from advancing edge. A $5 \mathrm{~mm}$ diameter of Trichoderma and soil borne fungi disks were placed on the opposite with a distance of 3 $\mathrm{mm}$ and incubated at room temperature. The soil borne fungi grown without Trichoderma were used as a negative control. Radial growth inhibition of soil borne fungi and overlapping growth by Trichoderma spp. were recorded and compared with the negative control. The percentage of inhibition was calculated as follows: $\% \mathrm{I}=[(\mathrm{C}-\mathrm{T}) / \mathrm{C}] \mathrm{x}$ 100 , where $\mathrm{I}=$ growth inhibition, $\mathrm{C}=$ radial growth of pathogens on negative control, $\mathrm{T}=$ radial growth of pathogens challenged with Trichoderma (Abo-Elyousr et al. 2014). The treatment was arranged in a Completely Randomized Design with three replicates.

\section{RESULTS AND DISCUSSION}

\section{Isolation of antagonistic fungi}

Antagonistic fungi offer environmentally friendly controls to suppress the incidence and severity of wilt caused by pathogens transmitted through the soil. Forty antagonist fungi obtained from different plant rhizospheres and soil were isolated and cultured on PDA during exploration around East Java, Indonesia (Table 1). All antagonistic fungi were identified as Trichoderma spp based on microscopic identification (Gams and Bissett 1998). This genus is easily isolated from soil with high organic compounds and plant roots as rhizosphere competence and endophytic fungi (Brotman et al. 2013; Cai et al. 2015) as was done in this study.

Radial growth of all isolates varied greatly (Table 2). The growth of the antagonistic fungi ranged from 0.1 to 0.8 $\mathrm{cm}$ on the first day of incubation on PDA. Three isolates of T9A, T21D, and T22E showed the slowest growth $( \pm 0.1$ $\mathrm{cm}$ ), whereas $\mathrm{T} 4 \mathrm{~B}, \mathrm{TPa} 1$, and $\mathrm{T} 15 \mathrm{~B}$ were the fastest 
growing isolates $( \pm 0.8 \mathrm{~cm})$. Trichoderma was categorized as fast growing fungi on general media such as potato dextrose-based media (Mishra et al. 2011; Tapwal et al. 2011; Jahan et al. 2013).

On the second day after inoculation, the radial growth of all isolates ranged from 0.6 to $3.1 \mathrm{~cm}$. The fastest growth isolate $( \pm 3.1 \mathrm{~cm})$ was about five times faster than the slowest growth isolate $( \pm 0.6 \mathrm{~cm})$. Most isolates fully covered the PDA three days after incubation. Fast growing isolates had the potential as antagonistic fungi since they were able to compete for the available space and nutrition which may inhibit the growth of plant pathogens (Brotman et al. 2010; Borrero et al. 2012; Abo-Elyousr et al. 2014).

Time of sporulation of all isolates was not significantly different ( $\mathrm{p}<0.05$ ) (Table 2). The isolates needed 2.5 to 4 days for sporulation after being cultured on PDA. Conidia produced by all Trichoderma isolates were qualitatively different as indicated by the different intensity of green colored mature conidia on PDA. Isolates of T 7A, T $17 \mathrm{C}$, $\mathrm{T}$ Pa1, and $\mathrm{T}$ Vil produced more conidia than other isolates. Isolates which produce abundant conidia are potential to be utilized as biocontrol agents, especially if conidia are encapsulated on seeds as seed treatments (Rao et al. 2015; Fiorentino et al. 2018).

Table 1. Trichoderma isolated from the rhizosphere of several plant species collected from different regions in East Java

\begin{tabular}{lll}
\hline Rhizosphere & Isolate origin & Code \\
\hline Sugar cane & Gending, Probolinggo & T 4, T 4A, T 4B \\
Onion & Gending, Probolinggo & T7A \\
Taro & Gending, Probolinggo & T 8B, T 8C \\
Chili & Alasrejo, Banyuwangi & T 9A \\
Mungbean & Genteng, Banyuwangi & T 14A \\
Mungbean (wilt) & Genteng, Banyuwangi & T 15A, T 15B, T \\
& & 15C \\
Soybean (wilt) & Genteng, Banyuwangi & T 16A \\
Taro & Genteng, Banyuwangi & T 17A, T 17B, T \\
& & $17 \mathrm{C}, \mathrm{T} 17 \mathrm{D}$ \\
Sweet potato & Genteng, Banyuwangi & T 18A \\
Paddy & Genteng, Banyuwangi & T 19A \\
Mungbean & Genteng, Banyuwangi & T 20A, T 20B \\
Mungbean & Genteng, Banyuwangi & T 21A, T 21B, T \\
& & $21 \mathrm{C}, \mathrm{T} \mathrm{21D}$ \\
Mungbean (wilt) & Genteng, Banyuwangi & T 22A, T 22C, T \\
& & $22 \mathrm{E}$ \\
Taro & Genteng, Banyuwangi & T 24A \\
Paddy & Rogojampi, & T 25A \\
& Banyuwangi & \\
Dioscorea & Genteng, Banyuwangi & T 26A \\
Cassava & Paiton, Probolinggo & T 36 \\
Soybean & Besuki, Situbondo & T 37 \\
Soybean & Genteng, Banyuwangi & T Au1 \\
Soybean & Genteng, Banyuwangi & T At1 \\
Peanut & Genteng, Banyuwangi & T Ci1 \\
Soybean & Genteng, Banyuwangi & T Ko1 \\
Peanut & Muneng, Probolinggo & T M6 \\
Peanut & Muneng, Probolinggo & T M20 \\
Soybean & Genteng, Banyuwangi & T Pa1 \\
Peanut & Genteng, Banyuwangi & T Vi1 \\
\hline & & \\
& &
\end{tabular}

\section{Antagonistic activity of Trichoderma against $R$. solani infected soybean}

Rahayu (2014) reported that $R$. solani (R.s1) caused damage on soybean in tidal swamp areas. In vitro antagonistic study of Trichoderma against $R$. solani (R.s1) showed that Trichoderma had promising inhibition (Figure 1). Several Trichoderma isolates inhibited about 50\% against $R$. solani (R.s1) after the third days of dual culture test, namely T 7A (51.8\%), T 8B (55.7\%), T 8C (56.3\%), and T M20 (54.4\%). Eight potential isolates inhibited $R$. solani (R.s1) up to $95-100 \%$, i.e. T 4A, T 22A, T At1, T 16A, T 15C, T 20B, T4, and T 15A. Microscopic observations of $\mathrm{T} 4$ and $\mathrm{T} 15 \mathrm{~A}$ isolates showed hyphal coiling of Trichoderma spp. over R. solani (R.s1) (Figure 2).

Tabel 2. The growth, sporulation time and conidia abundance of Trichoderma on Potato Dextrose Agar

\begin{tabular}{|c|c|c|c|c|}
\hline \multirow{2}{*}{ Isolate } & \multicolumn{2}{|c|}{ Radial growth $(\mathrm{cm})$} & \multirow{2}{*}{$\begin{array}{c}\begin{array}{c}\text { Green } \\
\text { sporulation } \\
\text { (dai) }\end{array} \\
\end{array}$} & \multirow{2}{*}{$\begin{array}{c}\text { Conidia } \\
\text { abundance }\end{array}$} \\
\hline & Day 1 & Day 2 & & \\
\hline T 4 & $0.25 \mathrm{opq}$ & 2.30 fghi & $3.0 \mathrm{a}$ & + \\
\hline $\mathrm{T} 4 \mathrm{~A}$ & $0.45 \mathrm{ijkl}$ & 2.59 bcde & $3.0 \mathrm{a}$ & + \\
\hline $\mathrm{T} 4 \mathrm{~B}$ & $0.78 \mathrm{ab}$ & $2.70 \mathrm{~b}$ & $3.0 \mathrm{a}$ & + \\
\hline $\mathrm{T} 7 \mathrm{~A}$ & $0.69 \mathrm{bc}$ & $2.93 \mathrm{a}$ & $3.0 \mathrm{a}$ & +++ \\
\hline $\mathrm{T} 8 \mathrm{~B}$ & 0.30 nop & $2.33 \mathrm{fgh}$ & $3.0 \mathrm{a}$ & ++ \\
\hline $\mathrm{T} 8 \mathrm{C}$ & 0.65 cde & $2.65 \mathrm{bcd}$ & $3.0 \mathrm{a}$ & ++ \\
\hline T 9A & $0.10 \mathrm{r}$ & $1.60 \mathrm{~m}$ & $3.5 \mathrm{a}$ & ++ \\
\hline $\mathrm{T} 14 \mathrm{~A}$ & 0.50 fghij & $2.39 \mathrm{efg}$ & $2.5 \mathrm{a}$ & ++ \\
\hline $\mathrm{T} 15 \mathrm{~A}$ & $0.20 \mathrm{pqr}$ & 2.13 hijk & $3.0 \mathrm{a}$ & ++ \\
\hline $\mathrm{T} 15 \mathrm{~B}$ & $0.85 \mathrm{a}$ & $3.03 \mathrm{a}$ & $3.0 \mathrm{a}$ & ++ \\
\hline $\mathrm{T} 15 \mathrm{C}$ & $0.25 \mathrm{opq}$ & $2.01 \mathrm{jkl}$ & $3.0 \mathrm{a}$ & ++ \\
\hline T 16A & 0.65 cde & $2.65 \mathrm{bcd}$ & $2.5 \mathrm{a}$ & ++ \\
\hline $\mathrm{T} 17 \mathrm{~A}$ & $0.40 \mathrm{jklmn}$ & $1.50 \mathrm{mn}$ & $3.0 \mathrm{a}$ & ++ \\
\hline $\mathrm{T} 17 \mathrm{~B}$ & $0.25 \mathrm{opq}$ & 1.881 & $4.0 \mathrm{a}$ & + \\
\hline $\mathrm{T} 17 \mathrm{C}$ & 0.49 ghijk & $2.50 \mathrm{bcdef}$ & $3.0 \mathrm{a}$ & +++ \\
\hline T 17D & 0.59 cdefg & $2.45 \mathrm{cdef}$ & $2.5 \mathrm{a}$ & ++ \\
\hline $\mathrm{T} 18 \mathrm{~A}$ & $0.68 \mathrm{bc}$ & 2.55 bcde & $3.0 \mathrm{a}$ & ++ \\
\hline T 19A & 0.59 cdefg & 2.56 bcde & $3.0 \mathrm{a}$ & ++ \\
\hline T 20A & $0.66 \mathrm{~cd}$ & $2.55 \mathrm{bcde}$ & $3.0 \mathrm{a}$ & ++ \\
\hline Т 20B & 0.48 hijk & $2.05 \mathrm{jkl}$ & $3.0 \mathrm{a}$ & ++ \\
\hline $\mathrm{T} 21 \mathrm{~A}$ & $0.18 \mathrm{qr}$ & $1.34 \mathrm{n}$ & $3.5 \mathrm{a}$ & ++ \\
\hline $\mathrm{T} 21 \mathrm{~B}$ & $0.40 \mathrm{jklmn}$ & $2.63 \mathrm{bcd}$ & $4.0 \mathrm{a}$ & + \\
\hline $\mathrm{T} 21 \mathrm{C}$ & $0.23 \mathrm{pq}$ & 2.19 ghij & $3.0 \mathrm{a}$ & + \\
\hline T 21D & $0.10 \mathrm{r}$ & $0.78 \mathrm{o}$ & $3.5 \mathrm{a}$ & ++ \\
\hline T 22A & 0.60 cdef & $2.66 \mathrm{bc}$ & $3.0 \mathrm{a}$ & + \\
\hline T 22C & 0.30 nop & $2.03 \mathrm{jkl}$ & $4.0 \mathrm{a}$ & + \\
\hline T 22E & $0.10 \mathrm{r}$ & $0.56 \mathrm{o}$ & $4.0 \mathrm{a}$ & ++ \\
\hline T 24A & $0.15 \mathrm{qr}$ & 1.851 & $4.0 \mathrm{a}$ & + \\
\hline $\mathrm{T} 25 \mathrm{~A}$ & $0.19 \mathrm{qr}$ & $2.10 \mathrm{ijk}$ & $3.0 \mathrm{a}$ & ++ \\
\hline T 26A & $0.34 \mathrm{mno}$ & $2.44 \mathrm{def}$ & $3.0 \mathrm{a}$ & + \\
\hline Т 36 & $0.20 \mathrm{pqr}$ & $1.50 \mathrm{mn}$ & $3.5 \mathrm{a}$ & ++ \\
\hline Т 37 & 0.55 efghi & $1.29 \mathrm{n}$ & $4.0 \mathrm{a}$ & + \\
\hline T M20 & 0.44 defgh & $2.38 \mathrm{efg}$ & $2.5 \mathrm{a}$ & ++ \\
\hline T M6 & 0.68 fghij & $3.06 \mathrm{a}$ & $3.0 \mathrm{a}$ & ++ \\
\hline T At1 & $0.36 \mathrm{bc}$ & $2.95 \mathrm{a}$ & $2.5 \mathrm{a}$ & ++ \\
\hline T Au1 & $0.61 \mathrm{jklm}$ & $2.03 \mathrm{jkl}$ & $3.0 \mathrm{a}$ & + \\
\hline T Ci1 & $0.50 \mathrm{lmn}$ & $2.03 \mathrm{jkl}$ & $3.0 \mathrm{a}$ & ++ \\
\hline T Ko1 & 0.56 cde & $2.94 \mathrm{a}$ & $3.0 \mathrm{a}$ & ++ \\
\hline T Pa1 & $0.83 \mathrm{a}$ & $2.96 \mathrm{a}$ & $2.5 \mathrm{a}$ & +++ \\
\hline $\mathrm{T}$ Vi1 & $0.39 \mathrm{klmn}$ & $1.95 \mathrm{kl}$ & $3.0 \mathrm{a}$ & +++ \\
\hline $\begin{array}{l}\text { Note: } s \\
\text { after in } \\
\text { by the } s\end{array}$ & $\begin{array}{l}\text { rulation: }+= \\
\text { ulation on } P \\
\text { me letter are } \\
=0.05\end{array}$ & $\begin{array}{l}\mathrm{w},++=\mathrm{m} \\
\text { Number } \\
\text { significar }\end{array}$ & $\begin{array}{l}\mathrm{n},+++= \\
\text { he same }\end{array}$ & $\begin{array}{l}\text { aty, dai }=\mathrm{d} \\
\text { Imn follow } \\
\text { d on the } L\end{array}$ \\
\hline
\end{tabular}




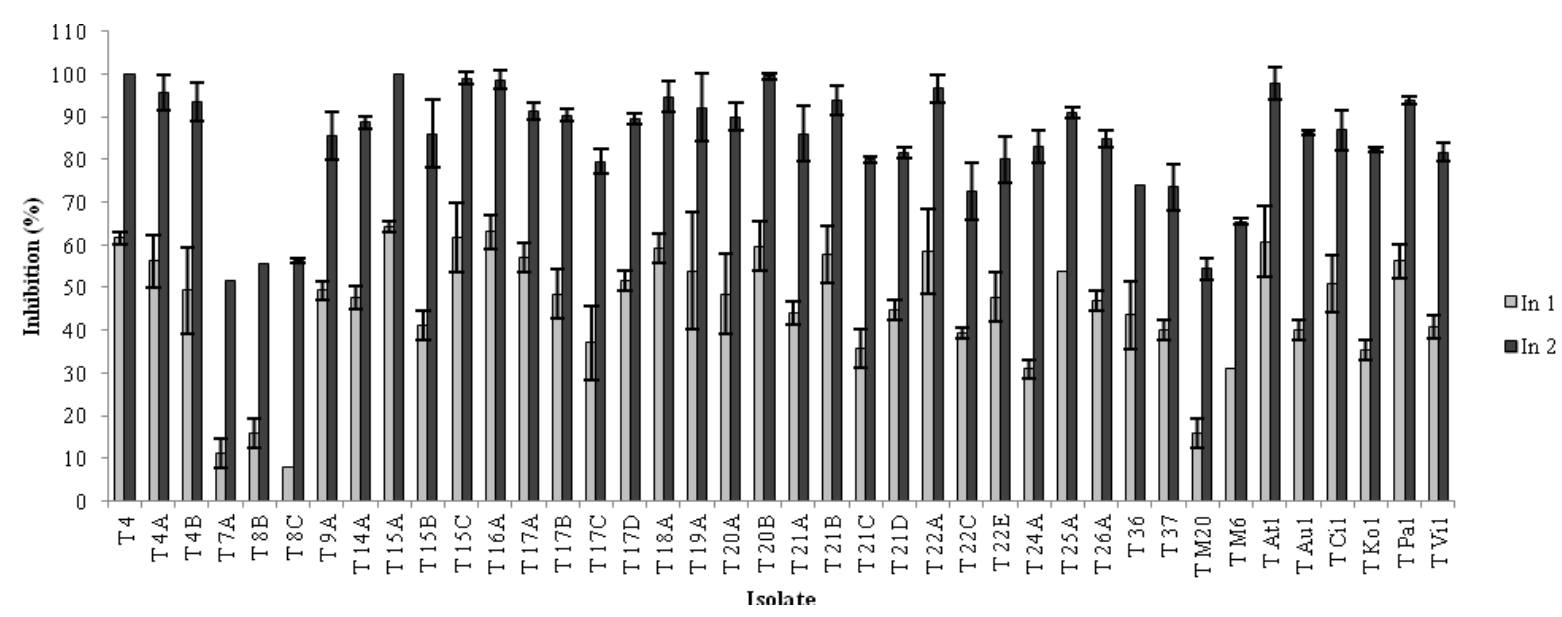

Figure 1. In vitro antagonism of Trichoderma against $R$. solani (Rs1). In $1=$ inhibition on day 2 , In $2=$ inhibition on day 3 on dual culture test. Error bars indicate standard deviations

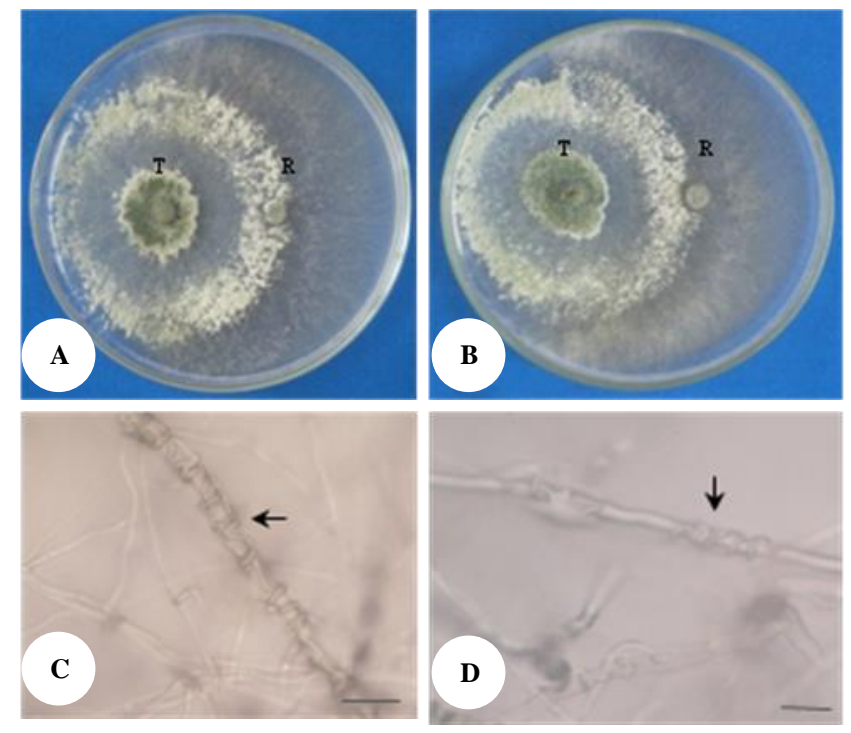

Figure 2. In vitro antagonism of $\mathrm{T} 4$ and $\mathrm{T} 15 \mathrm{~A}$ isolates against $R$. solani (R.s1) (a and b), and microscopic observation of $\mathrm{T} 4$ and $\mathrm{T}$ $15 \mathrm{~A}$ isolates against $R$. solani (R.s1) (c and d). T $=$ Trichoderma sp., $\mathrm{R}=R$. solani (R.s1). The arrow shows hyphal coiling of Trichoderma over $R$. solani (R.s1)

\section{Antagonistic activity of Trichoderma against $R$. solani infected mung bean}

Another isolate of $R$. solani (R.s2) which infected mung bean (Setyorini and Yusnawan 2014) was also challenged with Trichoderma. The highest suppression of Trichoderma against $R$. solani (R.s2) was less than $90 \%$ at the end of observation (Figure 3). The highest growth inhibition (87\%) against $R$. solani (R.s2) was obtained from $\mathrm{T} 24 \mathrm{~A}$ and $\mathrm{T}$ vil isolates, while other isolates inhibited $<87 \%$. Isolates of $\mathrm{T} 4$ and $\mathrm{T} 15 \mathrm{~A}$ which showed the most effective inhibition (100\%) against $R$. solani (R.s1), were only able to inhibit the growth of $R$. solani (R.s2) of $64.7 \%$ and $61.5 \%$, respectively. The results suggested that the same Trichoderma isolates had different antagonistic activity against different isolates of pathogens, although the pathogens were from the same species. Similar mechanism of Trichoderma coiling over R.solani (R.s2) was also observed in this study.

\section{Antagonistic activity of Trichoderma against Fusarium}

Fusarium sp. associated with wilt disease on mung bean as a secondary pathogen (Setyorini and Yusnawan 2014) was also challenged with Trichoderma spp. The results showed that no Trichoderma isolates were able to inhibit $100 \%$ the growth of Fusarium sp. (Figure 4). T 20A had the highest inhibition (90.8\%) against Fusarium sp. followed by isolates of $\mathrm{T} 15 \mathrm{C}$ and $\mathrm{T} 16 \mathrm{~A}$ (77.1\%), while isolates of $\mathrm{T} 4$ and $\mathrm{T} 15 \mathrm{~A}$ were only suppressed $55.7 \%$ and $57.2 \%$ the growth of Fusarium. Hypha of Trichoderma isolate grew over Fusarium on the last day of observation (Figure 5a). Microscopic observation showed that Fusarium was overlaid by Trichoderma hypha (Figure 5).

\section{Antagonistic activity of Trichoderma spp. against three isolates of the soil borne fungi}

Seven Trichoderma isolates had good inhibition against three isolates of soil borne fungi with the range of inhibition as follows: $R$. solani (R.s1) (90.0-99.6\%), $R$. solani (R.s2) (72.8-82.4\%), and Fusarium sp. (67.9-90.8\%) (Table 3). Radial growth of Trichoderma itself on PDA varied from 2.0 to $2.9 \mathrm{~cm}$ with the sporulation time varied from 2.5-3.0 days (Table 2). Although having different speed of radial growth when growing individually, the antagonistic properties of these Trichoderma spp. were not much different against each soil borne pathogen (Table 3), except for T 20A in inhibiting Fusarium sp.

Trichoderma has been widely used as a biological control against soil borne pathogens since several species show antagonistic properties both in vitro and in vivo (Morsy et al. 2009; Akrami et al. 2009). Current in vitro 
study showed that different Trichoderma isolated from different rhizospheres had different antagonistic activities against different isolates of phytopathogenic fungi. This finding suggested that the genetic variability of antagonistic isolates played an important role in biocontrol activity. The results of this study were in agreement with a study conducted by Moosa et al. (2017) in which the variability of antagonistic activity depends on the isolate genetic potential and its origin.

It was demonstrated that seven Trichoderma isolates had an antagonistic activity to suppress the growth of three soil borne pathogens with different levels of inhibition. The results showed that one isolate could inhibit the growth of several soil borne pathogens. The highest antagonistic activity in this present study was greater than that of Trichoderma T021 isolate $(72.77 \%$ inhibition) in suppressing the growth of $R$. solani infected Phaseolus vulgaris as reported by Mayo et al. (2015). Nevertheless, when compared with inhibition percentage of of Trichoderma isolates of Tv-2, Th-7, and Th-5 (79.2 $82.8 \%$ ) against $F$. oxysporum f.sp. lentis (Sharfuddin and Mohanka 2012), inhibition of the seven Trichoderma isolates $(67.9-70.9 \%)$ against Fusarium sp. in the current study showed lower inhibition values. The study conducted by Sharfuddin and Mohanka (2012), however, only used one fitopathogen species to test Trichoderma antagonistic activity.

The mycelial growth of the selected Trichoderma over the mycelial of soil borne pathogens showed hyperparasitism phenomenon that responsible for the antagonistic mechanism (Doley and Jite 2012) as shown in this study. In addition to hyperparasitism properties, Trichoderma is also able to grow very fast so that it can occupy space and compete in the use of nutrients (Devi et al. 2012). Microscopic observations showed hyphal coiling of the pathogens by the indigenous Trichoderma (Figure 2 and 5). Several mechanisms occurred during coiling, including producing enzymes of the antagonistic fungi which degrade the cell wall of the pathogens such as chitinase, cellulose, $\beta$-1,3-glucanase, $\beta$-1,6-glucanase, and protease. These enzymes play important roles during mycoparasitism as well as hyphal colonization (Küçük and Kývanç 2008; Jayalakshmi et al. 2009).

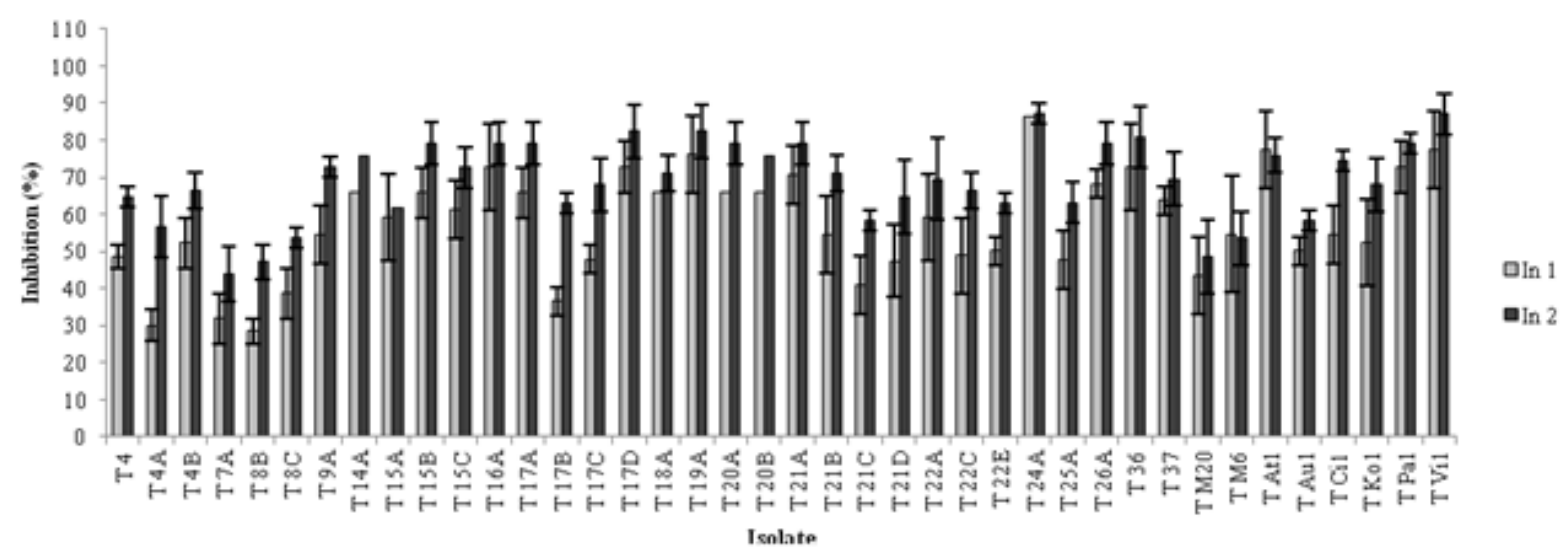

Figure 3. In vitro antagonism of Trichoderma against $R$. solani (Rs2). In $1=$ inhibition on day 3 ; In $2=$ inhibition on day 4 on dual culture test. Error bars indicate standard deviations

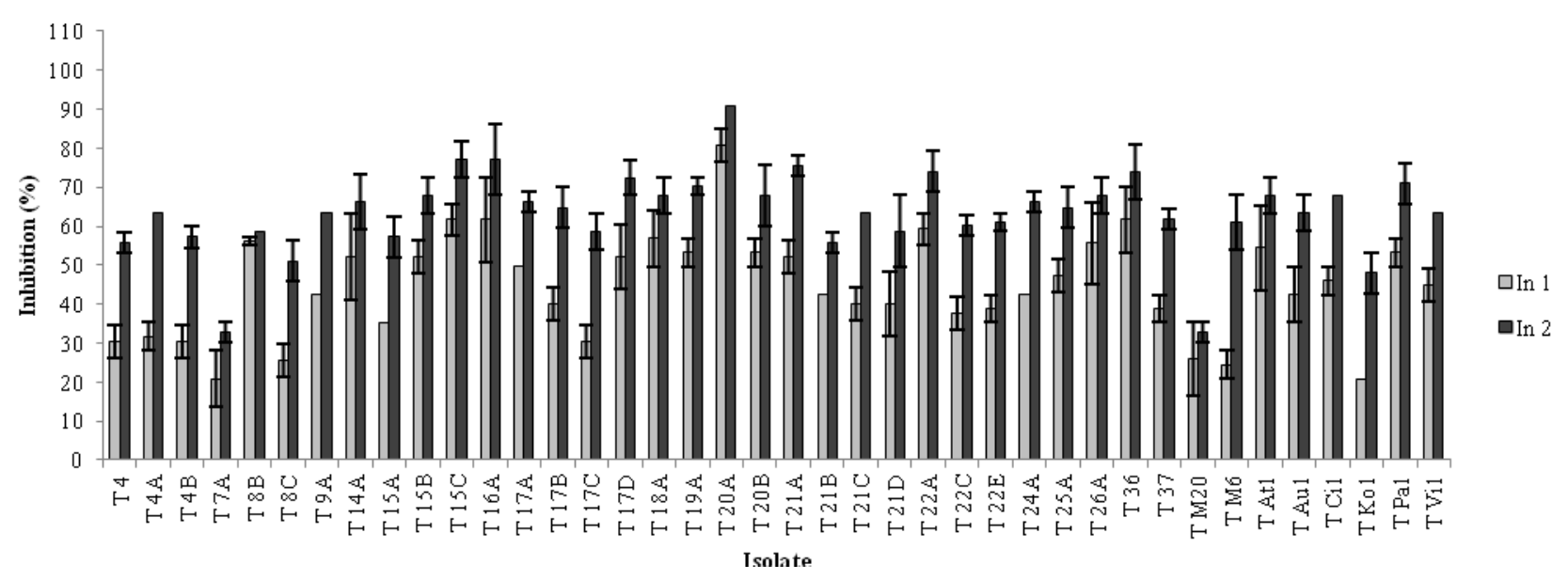

Figure 4. In vitro antagonism of Trichoderma against Fusarium sp. In $1=$ inhibition on day 3, In $2=$ inhibition on day 4 on dual culture test. Error bars show standard deviations. 

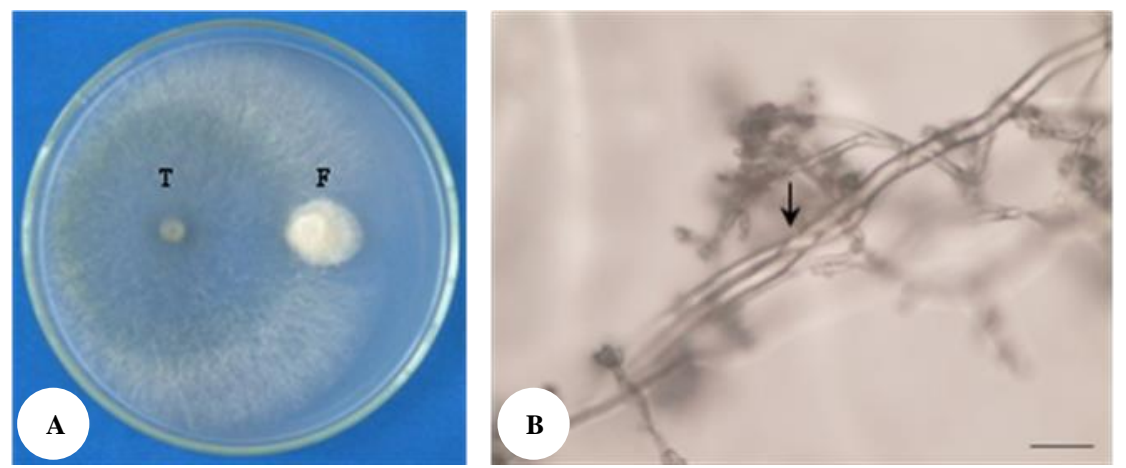

Figure 5. In vitro antagonism of Trichoderma isolate of T 20A against Fusarium sp. (A), and microscopic observation of T 14A isolate against Fusarium sp. (B). T = Trichoderma sp., F = Fusarium sp. The arrow shows coiling of Trichoderma over Fusarium sp.

Table 3. Growth inhibition of Trichoderma spp. against different isolates of soil borne pathogens

\begin{tabular}{llll}
\hline \multirow{2}{*}{ Trichoderma } & \multicolumn{3}{c}{ Inhibition (\%) } \\
\cline { 2 - 4 } & $\begin{array}{c}\text { R. solani } \\
\text { (R.s1) }\end{array}$ & $\begin{array}{c}\text { R. solani } \\
\text { (R.s2) }\end{array}$ & $\begin{array}{c}\text { Fusarium } \\
\text { sp. }\end{array}$ \\
\hline T 20A & $90.0 \mathrm{c}$ & $79.2 \mathrm{ab}$ & $90.8 \mathrm{a}$ \\
T 19A & $92.2 \mathrm{bc}$ & $82.4 \mathrm{a}$ & $70.2 \mathrm{bc}$ \\
T Pa1 & $93.9 \mathrm{abc}$ & $79.2 \mathrm{ab}$ & $70.9 \mathrm{bc}$ \\
T At1 & $97.8 \mathrm{ab}$ & $76.0 \mathrm{ab}$ & $67.9 \mathrm{c}$ \\
T 16A & $98.7 \mathrm{ab}$ & $79.2 \mathrm{ab}$ & $77.1 \mathrm{~b}$ \\
T 15C & $99.1 \mathrm{a}$ & $72.8 \mathrm{~b}$ & $77.1 \mathrm{~b}$ \\
T 20B & $99.6 \mathrm{a}$ & $76.0 \mathrm{ab}$ & $67.9 \mathrm{c}$ \\
\hline
\end{tabular}

Note: numbers followed by the same letters in the same column are not significantly different based on the LSD test $(\alpha=5 \%)$

Trichoderma isolated from crop rhizosphere as performed in this study might have rhizosphere competence ability. This interaction between Trichoderma and plants triggers plant growth and increases plant nutrient absorption (Harman et al. 2004). The ability of antagonistic fungi to increase plant health through the induction of systemic resistance to plant pathogens is reported in some species of Trichoderma. Gajera et al. (2015) reported that $T$. viride induced plant resistant by activating phenylpropanoid pathway to increase polyphenol oxidase and phenylalanine ammonia lyases. Another study by Christopher et al. (2010) showed that there is an increase in enzymes which belongs to the pathogenesis-related proteins such as the polyphenol oxidase and phenylalanine ammonium lyase activity. An increase in total phenolic contents after $T$. virens colonization was also reported (Christopher et al. 2010). Further study will be done to determine the benefits of the interaction between selected Trichoderma from this study and leguminous crops, and also the identification of Trichoderma species by molecular work.

In summary, seven isolates of Trichoderma ( $\mathrm{T}$ At1, $\mathrm{T}$ 15C, T 16A, T 19A, T 20A, and T 20B) had potent antagonistic activity against $R$. solani (R.s1), R. solani (R.s2) and Fusarium sp in vitro. Competition of space and nutrition, as well as mycoparasitism, was performed by these selected Trichoderma. These antagonistic fungi are promising as biocontrol agents against multi-isolates of phytopathogens. The protective ability of the selected Trichoderma to plants and the role of these antagonists to induce systemic resistance need to be further studied.

\section{ACKNOWLEDGMENTS}

This work was financially supported by the Indonesian government, and this support is highly appreciated.

\section{REFERENCES}

Abo-Elyousr KA, Abdel-Hafez, SI, Abdel-Rahim IR. 2014. Isolation of Trichoderma and evaluation of their antagonistic potential against Alternaria porri. J Phytopathol 162(9): 567-574.

Agamani P, Bhagat S, Biswas M, Viswanath K. 2017. Effect of volatile and non volatile compounds of Trichoderma spp. against soil borne diseases of chickpea. Int J Current Microbiol Appl Sci 6(7): 14861491.

Ajith PS, Lakshmidevi N. 2010. Effect of volatile and non-volatile compounds from Trichoderma spp. against Colletotrichum capsici incitant of anthracnose on bell peppers. Nat Sci 8(9): 265-269.

Akhter W, Bhuiyan MKA, Sultana F, Hossain MM. 2015. Integrated effect of microbial antagonist, organic amendment and fungicide in controlling seedling mortality (Rhizoctonia solani) and improving yield in pea (Pisum sativum L.). Comptes Rendus Biologies 338(1): 21-28.

Akrami M, Ibrahimov AS, Zafari DM, Valizadeh E. 2009. Control Fusarium rot of bean by combination of by Trichoderma harzianum and Trichoderma asperellum in greenhouse condition. Agric J 4(3): 121-123.

Borrero C, Trillas M, Delgado A, Avilés M. 2012. Effect of ammonium/nitrate ratio in nutrient solution on control of Fusarium wilt of tomato by Trichoderma asperellum T34. Plant Pathol 61(1): 132-139.

Brotman Y, Kapuganti JG, Viterbo A. 2010. Trichoderma. Curr Biol 20(9): R390-R391.

Brotman Y, Landau U, Cuadros-Inostroza Á, Takayuki T, Fernie AR, Chet I, et al. 2013. Trichoderma-plant root colonization: escaping early plant defense responses and activation of the antioxidant machinery for saline stress tolerance. PLoS Pathog: 9(3): e1003221.

Cai F, Chen W, Wei Z, Pang G, Li R, Ran W, et al. 2015. Colonization of Trichoderma harzianum strain SQR-T037 on tomato roots and its 
relationship to plant growth, nutrient availability and soil microflora. Plant Soil 388(1-2): 337-350.

Christopher DJ, Raj TS, Rani SU, Udhayakumar R. 2010. Role of defense enzymes activity in tomato as induced by Trichoderma virens against Fusarium wilt caused by Fusarium oxysporum f sp. lycopersici. J Biopesticides 3(1): 158.

Datta S, Dey P, Sarkar A, Tarafdar J, Chowdhury A. 2016. Comparison among four triazole fungicides on growth and development of sheath blight of rice pathogen Rhizoctonia solani Kühn AG1-1A. Arch Phytopathol Plant Prot 49(9-10): 239-251.

Devi SS, Sreenivasulu Y, Saritha S, Kumar MR, Kumar KP, Sudhakar P. 2012. Molecular diversity of native Trichoderma isolates against Fusarium oxysporum f. sp. lycopersici (Sacc.). a casual agent of Fusarium wilt in tomato (Lycopersicon esculentum Mill.). Arch Phytopathol Plant Protec 45(6): 686-698.

Doley K, Jite, PK. 2012. In vitro efficacy of Trichoderma viride against Sclerotium rolfsii and Macrophomina phaseolina. Not Sci Biol 4(4): 39.

Dubey SC, Suresh M, Singh B. 2007. Evaluation of Trichoderma species against Fusarium oxysporum f. sp. ciceris for integrated management of chickpea wilt. Biol Control 40(1): 118-127.

Fiorentino N, Ventorino V, Woo SL, Pepe O, De Rosa A, Gioia L, Romano I, Nadia L, Napolitano M, Colla G. 2018. Trichodermabased biostimulants modulate rhizosphere microbial populations and improve $\mathrm{N}$ uptake efficiency, yield, and nutritional quality of leafy vegetables. Front Plant Sci 9(743): 1-15.

Gajera H, Savaliya DD, Patel S, Golakiya B. 2015. Trichoderma viride induces pathogenesis related defense response against rot pathogen infection in groundnut (Arachis hypogaea L.). Infect Genet Evol 34: 314-325.

Gams W, Bissett J. 1998. Morphology and identification of Trichoderma. In: Kubicek CP, Harman GE (eds.), Trichoderma \& Gliocladium (Vol. 1, pp. 3-34): Taylor \& Francis, New York.

Harman GE, Howell CR, Viterbo A, Chet I, Lorito M. 2004. Trichoderma species-opportunistic, avirulent plant symbionts. Nat Rev Microbiol 2(1): 43.

Jahan N, Sultana S, Adhikary S, Rahman S, Yasmin S. 2013. Evaluation of the growth performance of Trichoderma harzianum (Rifai.) on different culture media. IOSR J Agric Vet Sci (IOSR-JAVS) 3(4): 4450.

Jayalakshmi S, Raju S, Rani SU, Benagi V, Sreeramulu K. 2009. Trichoderma harzianum $\mathrm{L} 1$ as a potential source for lytic enzymes and elicitor of defense responses in chickpea (Cicer arietinum L.) against wilt disease caused by Fusarium oxysporum f. sp. ciceri. Aust J Crop Sci 3(1): 44

John NS, Anjanadevi I, Nath VS, Sankar SA, Jeeva ML, John KS, Misra RJ. 2015. Characterization of Trichoderma isolates against Sclerotium rolfsii, the collar rot pathogen of Amorphophallus-A polyphasic approach. Biological Control 90: 164-172.

John RP, Tyagi R, Prévost D, Brar SK, Pouleur S, Surampalli R. 2010. Mycoparasitic Trichoderma viride as a biocontrol agent against Fusarium oxysporum f. sp. adzuki and Pythium arrhenomanes and as a growth promoter of soybean. Crop Prot 29(12): 1452-1459.

Küçük Ç, Kývanç M. 2008. Mycoparasitism in the biological control of Gibberella zeae and Aspergillus ustus by Trichoderma harzianum strains. J Agric Technol 4: 49-55.

Mahmoud AF, Abdalla OA. 2018. Biocontrol efficacy of Trichoderma spp. against sesame wilt caused by Fusarium oxysporum f. sp. sesami. Arch Phytopathol Plant Protec: 1-11.
Mayo S, Gutierrez S, Malmierca MG, Lorenzana A, Campelo MP, Hermosa R,Casquero PA. 2015. Influence of Rhizoctonia solani and Trichoderma spp. in growth of bean (Phaseolus vulgaris L.) and in the induction of plant defense-related genes. Front Plant Sci 6 (685): $1-11$

Mishra B, Mishra RK, Mishra R, Tiwari AK, Yadav RS, Dikshit A. 2011. Biocontrol efficacy of Trichoderma viride isolates against fungal plant pathogens causing disease in Vigna radiata L. Arch Appl Sci Res 3(2): 361-369.

Moosa A, Sahi ST, Haq IU, Farzand A, Khan SA, Javaid K. 2017. Antagonistic potential of Trichoderma isolates and manures against Fusarium wilt of tomato. Int J Vegetable Sci 23(3): 207-218.

Morsy EM, Abdel-Kawi K, Khalil M. 2009. Efficiency of Trichoderma viride and Bacillus subtilis as biocontrol agents gainst Fusarium solani on tomato plants. Egypt J Phytopathol 37(1): 47-57.

Rahayu M. 2014. Identification and pathogenicity of pathogen responsible for aerial blight disease of soybean. J Exp Biol 2: 2S.

Rao GS, Reddy NNR, Surekha C. 2015. Induction of plant systemic resistance in Legumes Cajanus cajan, Vigna radiata, Vigna mungo against plant pathogens Fusarium oxysporum and Alternaria alternata-a Trichoderma viride mediated reprogramming of plant defense mechanism. Int J Recent Sci Res 6(5): 4270-4280.

Rosmana A, Samuels GJ, Ismaiel A, Ibrahim ES, Chaverri P, Herawati Y, Asman A. 2015. Trichoderma asperellum: A dominant endophyte species in cacao grown in Sulawesi with potential for controlling vascular streak dieback disease. Trop Plant Pathol 40(1): 19-25.

Saravanakumar K, Yu C, Dou K, Wang M, Li Y, Chen J. 2016. Synergistic effect of Trichoderma-derived antifungal metabolites and cell wall degrading enzymes on enhanced biocontrol of Fusarium oxysporum f. sp. cucumerinum. Biol Control 94: 37-46.

Setyawan B, Rouf A, Setiono. 2014. Evaluation of Trichoderma spp. isolates combination for biological control of white root disease in rubber. In Purwono, Soeharto, Juarini, S. Wardoyo, Sumarwoto, O. S. Padmini (eds.) Proceeding of National Seminar of Sustainable Bioindustry Agriculture (pp. 239-246). UPN Veteran Yogyakarta, 11 December 2014. [Indonesian]

Setyorini SD, Yusnawan E. 2014. Fungi associated with wilt disease on mung bean germplasm. In: Purwono, Soeharto, Juarini, Wardoyo S. Sumarwoto O, Padmini S. (eds.) Proceeding of National Seminar of Sustainable Bioindustry Agriculture (pp. 255-262). UPN Veteran Yogyakarta, 11 December 2014. [Indonesian]

Sharfuddin C, Mohanka R. 2012. In vitro antagonism of indigenous Trichoderma isolates against phytopathogen causing wilt of lentil. Int J Life Sci Pharm Res 2: 195-202.

Sundaramoorthy S, Balabaskar P. 2013. Biocontrol efficacy of Trichoderma spp. against wilt of tomato caused by Fusarium oxysporum f. sp. lycopersici. J Appl Biol Biotechnol 1(03): 36-40.

Tapwal A, Singh U, Singh G, Garg S, Kumar R. 2011. In vitro antagonism of Trichoderma viride against five phytopathogens. Pest Technol 5(1): 59-62.

Woo SL, Ruocco M, Vinale F, Nigro M, Marra R, Lombardi N, Pascale A, Lanzuise S, Manganiello G, Lorito M. 2014. Trichoderma-based products and their widespread use in agriculture. Open Mycoly J 8(1): $71-126$

You J, Zhang J, Wu M, Yang L, Chen W, Li G. 2016. Multiple criteriabased screening of Trichoderma isolates for biological control of Botrytis cinerea on tomato. Biol Control 101: 31-38. 